\title{
Simgesel Bir Form Olarak Perspektiften Dinin Seküler İnşasına Mekânın Poetikası
}

\author{
İran Kaya \\ Dr. Öğr. Üyesi, Sivas Cumhuriyet Üniversitesi (ROR ID: 04f81fm77) \\ İlahiyat Fakültesi, Din Sosyolojisi Ana Bilim Dalı \\ Assist. Prof. Dr., Sivas Cumhuriyet University, Faculty of Theology, Department of Sociology of Religion \\ Sivas/Turkey \\ ikaya@cumhuriyet.edu.tr \\ ORCID: 0000-0002-8761-7489
}

\section{Poetics of Space from Perspective as a Symbolic Form to Secular Construction of Religion}

\begin{abstract}
The discovery of the artist-specific perspective with the joint efforts of Alberti and Brunelleschi in the 15th century has been a decisive step and a real milestone on the long path to modern methods applied in the concept of modern space and its implementation. The idea of a perspective to seize the space by creating depth on a two-dimensional canvas stands between the view of the space, which is well established in collective and individual realities, and the displacement of the space in the following modern era and regardless of the determining role of human perception in the organization of the space.

While the unity of drama in Aristotle's Poetics was the founding element that shaped the world of Western literature, perspective and Euclidean geometry were also determinant in the poetics of Western urban architecture. Such an effort to standardize everything has been a characteristic of Western thought since Ancient Greece. The western thought that embraced reaching certainty, obligation, and then universal is also consistent with the idea of mastery. Therefore, in such a thought that gives order and commends control, a poetics about space made it possible to build cities in garrison style, surrounded by walls and on a hierarchical system.

The article examines the urban space poetics through the perspective as a symbolic form. In doing so, connections have been established between vision and perspective, perspective and space, space and modern religion. Therefore, in the first part of the study, the subject of perspective is addressed within the framework of the tense relationship between social life and forms. In the second part, although the perspective has emerged as a form, the will to organize different areas of life is opened to discussion. In the last part, criticism of the secular view of religion, whose borders are drawn in the urban space, which has disintegrated as a result of the regulation practice is addressed. Thus, beyond being only a technique in drawing and painting, perspective is regarded as an embodied practice of modern episteme in thought, vision, a city's
\end{abstract}

İntihal Taraması/Plagiarism Detection: Bu makale intihal taramasından geçirildi/This paper was checked for plagiarism Geliş/Received: 20 Mayıs/May 2020 |Kabul/Accepted: 07 Ağustos/August 2020 | Yayın/Published: 20 Eylül/September 2020 Atıf/Cite as: İrfan Kaya, "Simgesel Bir Form Olarak Perspektiften Dinin Seküler İnşasına Mekânın Poetikası = Poetics of Space from Perspective as a Symbolic Form to Secular Construction of Religion", Eskiyeni 41 (Eylül/September 2020), 491-513. https://doi.org/10.37697/eskiyeni.740323

Copyright @ A Anadolu İlahiyat Akademisi/Anatolian Theological Academy, 06050, Ankara, Turkey | www.anilakademi.com CC BY-NC 4.0 | This paper is licensed under a Creative Commons Attribution-NonCommercial License 
societal and religious space. This study is the product of an effort to understand the fundamental parameters of the modern episteme, on which modern life is built, and the motives with which it is formed. In this direction, as vision regimes that determine the understanding of space in the modern period Western city and architecture, connections between perspective, camera obscura, and the panoptic system that shapes a modern society with a model are traced. As the subject of the research is architecture and urban structure, the style and method of the article are inevitably deconstruction.

The invention of painting, which is called perspective, has revolutionized the history of vision. When the view is considered the referee of art, the world becomes a painting as Heidegger states. The view that an audience turns into the world is presented for the first time through perspective. Therefore, it is ensured that the audience reaches a privileged position by putting the viewer in front of the painting with the perspective for taking the space over. In short, the humanist spirit of the Renaissance was breathed into perspective. The fixed perspective of maps and images based on perspective is glorified and distant; and a universal eye concept that is the same everywhere remains the same everywhere, homogenizes, is essential. Perspectivism and mathematical cartography do this through an abstract, homogeneous, and universal understanding of space as a fixed and knowable framework of thought and action.

The parceling of the space with a holistic perspective due to maps has made the intervention open by separating social life as public space and private space. The characterization of the public sphere with rationality after Kant was effective in pulling the religion, which started to be used as a counterpart to the belief of "the inner world of man", from the public sphere. The efforts of important public figures such as John Locke to isolate the beliefs about God in a private area led to the confinement of religion in certain places. In other words, religion is included in the social life of the city through the policy of exclusion. Yet, it is the politics of exclusion that draws the boundaries of the city and the urban social life, and thus making it possible for the establishment of these. Those who are excluded create the identity of the modern city. It needs this "outside" to create its unique, pure identity. While religion is left out of public life, it also determines the boundary of public space. The fragmentation of the urban space in the form of a center-environment led to the perception of things "belonging to the outside world such as life, freedom, health, wealth, land, money" as intervenable for the public interests as secular spaces, and the religion to create an "inner world, separate from secular and protected from political authority.". Therefore, the increased visibility of religion in public space is perceived as the occupation of the secular space. Thus, the imprisonment of religion in a certain place has become indispensable for the control of religion.

\section{Keywords}

Sociology of Religion, Perspective, Space, City, Secular

\section{Simgesel Bir Form Olarak Perspektiften Dinin Seküler İnşasına Mekânın Poetikası Öz}

15. yüzyılda, Alberti ve Brunelleschi'nin ortak çabalarıyla ressama özgü perspektifin keşfi, modern mekân kavramında ve onu hayata geçirmede uygulanan modern yöntemlere giden uzun yolda belirleyici bir adım ve gerçek bir dönüm noktası olmuştur. İki boyutlu bir tuval üzerinde derinlik yaratmak suretiyle mekânı ele geçirmeye matuf perspektif fikri, kolektif ve bireysel gerçeklikler içine iyice yerleşmiş mekân görüşü ile mekânın takip eden modern çağdaki yerinden çıkmışlığı arasında durmakta ve mekânın örgütlenmesinde insan algısının belirleyici rolünü tartışmasız kabul etmektedir. 
Aristo'nun Poetika'sında ortaya koyduğu dram birliği Batı edebiyatı ve yazın dünyasını şekillendiren kurucu öge olurken, perspektif ve Öklidci geometri de Batılı kent mimarisinin mekâna dair poetikasında belirleyici olmuştur. Her şeyi standardize etmeye yönelik böylesi bir çaba Batı düşüncesinin Antik Yunan'dan bu yana karakteristik özelliği olmuştur. Batı düşüncesinin kendisine kesinlik, zorunluluk ve oradan da evrensel olana ulaşmayı şiar edinmiş olması hâkim olma düşüncesiyle de tutarlılık arz etmektedir. Dolayısıyla düzeni ve kontrolü salık veren böylesi bir düşüncede mekâna dair bir poetika; garnizon tarzı, etrafı surlarla çevrili ve hiyerarşik dizge üzerine kentlerin kurulmasını mümkün hale getirmiştir.

Makale, simgesel bir form olarak perspektif üzerinden kentsel mekân poetikasını inceleme konusu yapmaktadır. Bunu yaparken görme ile perspektif, perspektif ile mekân, mekân ile modern din anlayışı arasında bağlantılar kurulmuştur. Bu maksatla çalışmanın birinci bölümünde, perspektif konusu, toplumsal hayat ile formlar arasındaki gergin ilişki çerçevesinde ele alınmıştır. İkinci bölümde ise, perspektifin bir form olarak içinden çlkmış olmasına rağmen hayatın farklı alanlarını düzenleme iradesi tartışmaya açılmıştır. Son bölümde ise, düzenleme pratiğinin neticesinde parsellenen kent mekânında sınırları çizilen dine dair seküler bakış eleştiri konusu yapılmıştır. Dolayısıyla perspektif, çizimde ve resimde sadece bir teknik olmanın çok daha ötesinde düşüncede, görmede, kentin toplumsal ve dinî mekânında modern epistemenin düzenleme pratiği olarak karşımıza çıkmaktadır. Bu çalışma, son tahlilde günümüz modern hayatın üzerine bina edildiği modern epistemenin temel parametrelerinin neler olduğunu ve hangi saiklerle oluştuğunu anlama çabasının bir ürünüdür. Bu doğrultuda modern dönem Batılı kent ve mimarinin mekân anlayışını belirleyen birer görme rejimleri olarak perspektif, camera obscura ile bir model olarak modern toplumu şekillendiren panoptik sistem arasındaki bağlantıların izi sürülmektedir. Araştırma konusu mimari ve kent yapılanması olunca makalenin tarzı ve yönteminin yapıbozum olması kaçınılmazdır.

Perspektif dediğimiz resim icadı, görmenin tarihinde bir devrim yaratmıştır. Bakış sanatın hakemi yapılınca, Heidegger' in ifadesiyle dünya resim olur. Bir izleyicinin dünyaya çevirdiğibakış ilk kez perspektif sayesinde ortaya konur. Dolayısıyla mekânın ele geçirilmesinin amaçlandığı perspektif ile izleyicinin resmin önüne konmak suretiyle ayrıcalıklı bir konuma erişmesi de sağlanmış olur. Kısacası, perspektife Rönesans'ın hümanist ruhundan üflenmiștir. Perspektife dayalı harita ve resimlerin sabitleștirilmiş bakış açısı yüceltilmiş ve mesafelidir; her yerde aynı olan, her yerde aynı kalan, homojenleștiren, evrensel bir göz anlayışı esastır. Perspektivizm ve matematiksel haritacılık bunu, mekânı nitelikleri bakımından soyut, türdeş ve evrensel olarak, düşünce ve eylemin sabit ve bilinebilir çerçevesi olarak kavrama yoluyla yapmaktadır.

Mekânın haritalar sayesinde bütünselleştirici bir bakış açısı ile parsellenmesi, toplumsal hayata, kamusal alan ve özel alan şeklinde ayrıştırarak müdahaleyi de açık hale getirmiştir. Kamusal alanın Kant sonrasında rasyonellikle karakterize edilmesi, "insanın iç dünyasına ait" bir inancın karşılığı olarak kullanılmaya başlanan religionın kamusal alandan çekilmesinde etkili olmuştur. John Locke gibi önemli kamu figürlerinin, Tanrıyla ilgili inanışları özel bir alanda izole etme çabası dinin belli mekânlara hapsedilmesine yol açmıştır. Başka bir deyişle din, kentin toplumsal hayatına dışlama siyaseti üzerinden dâhil olur. Zira kentin ve kentsel toplumsal yaşamın sınırını çizen, dolayısıyla bunların kurulmasını mümkün kılan şey, dışlama siyasetidir. Asıl dışarıda tutulanlar modern kentin kimliğini yaratır. Benzersiz, saf kimliğini oluşturmak için bu "dışarıya" ihtiyacı vardır. Din, kamusal yaşamın dışına terk edilirken, tersinden kamusal mekânın sınırını da belirlemiş olur. Kent mekânının merkez-çevre şeklinde parçalanması, “yaşam, özgürlük, sağlık, varlık, toprak, para gibi dış dünyaya ait” şeylerin seküler alanlar olarak kamunun çıkarları için müdahale edilebilir olarak algılanmasına, religionın ise "iç dünyaya ait, 
sekülerden ayrı ve siyasi otoriteden korunmuş alanı" oluşturmasına karar verilmiştir. Bu yüzden olsa gerek, dinin kamusal mekânda görünürlüğünün artması, seküler alanın işgale uğraması olarak algılanmaktadır. 0 yüzdendir ki, dinin belli bir mekâna hapsedilmesi, dinin kontrolü için vazgeçilmez olmuştur.

\section{Anahtar Kelimeler}

Din Sosyolojisi, Perspektif, Mekân, Kent, Seküler

\section{Giriş}

İnsan duyuları içerisinde en öne çıkanı, bir gösteri toplumunda yaşadığımıza göre modern kültürün üretimcisi olarak düşünülen görmedir (vision). Martin Jay, Rönesans'ın kültürel habitusunda şekillenmeye başlayan modernitenin göz-merkezcil (acularcentric) olduğunu söyler. ${ }^{1}$ Göze atfedilen bu üstünlük sayesinde Avrupalı dik durduğunu ve doğru baktığını düşünmektedir. Barok dönemde bu Tanrısal göze Teslis' in geometrik simgesi olan üçgen de eklenmiş, Fransız Devrimi'nde göz bu biçimiyle yeni toplumsal düzenin simgesi haline gelmiştir. ${ }^{2}$ Ayrıca Rönesans’a özgü, gözün gördüğüyle hakikatin bir ve aynı şey olduğu anlayışı, görü ile bilginin eşit konuma gelmesini sağlamıştır. Böylece görme felsefeden bilime, sosyolojiden sanata kadar pek çok bilgi türünü görünür kılarak bakış açısı kazanmasına olanak tanımıştır. Artık hakikatin göze gelmesiyle dış dünyaya, 15. yüzyıldan itibaren çılak bir bedene bakar gibi bakılmaktadır. Başka bir deyişle ampirik dünya görsel bilginin nesnesi haline gelmiş olmaktadır.

Lacan, silahları bırakır gibi bakışın bırakıldı̆̆ı bir imgeye arzu duyar. ${ }^{3}$ Bakıştaki şiddeti açımlama adına, her ne kadar mitolojik bir karakter olsa da Orpheus, sonuçta arkasına dönüp baktığı ve bakışıyla yaşam ile ölüm arasındaki yasak eşiği aştığı için sevdiği kadın Eurydike’yi bir kez daha kaybetmişti. Bakışla ilgili diğer mitolojik hikâye de kocası Poseidon'la olan ilişkisini duyması üzerine Athena'nın güzelliğiyle bilinen Medusa'yı cezalandırma şekliyle ilgilidir. Athena Medusa ve kız kardeşlerini Gorgo denilen kanatlı, yılan saçlı ve korkunç yüzlü yaratıklara dönüştürür. Medusa, artık o kadar çirkindir ki kimse yüzüne bakmaya cesaret edemez. Öyle ki Medusa'nın/Gorgo'nun bakışı, kurbanlarını cansız taşlara, yani bir bakışa bakışlarıyla karşılık veremeyen ölü resimlere dönüştürecek güçtedir.

Acaba görü ile bilgiyi eşitleyen bilimsel bakışın da tıpkı Medusa'nın bakışı gibi hayatı taşlaştırdığı söylenebilir mi? Sosyolojide fenomenolojik bir yöntem olarak sıklıkla başvurulan epoke, nihayetinde özne ile nesne arasına, düşünce ile imge arasına

1 Martin Jay, “Scopic Regimes of Modernity”, ed. Hal Foster, Vision an Visuality (Seattle: Bay Press, 1988), 3.

2 Aslında üçgen, Aristo mantığının matematik açısından görsel izdüşümünü temsil eder. Antik Yunanlıların geometriye (Öklid geometrisi) hayranlığı buradan kaynaklanmaktadır. Üçgenin dolayısıyla genel olarak geometrinin aracı konuma getirilmesi, kullanımdaki kasdı, düşüncenin ve doğal yansıması olan yaşamın, görüntünün, söylemin ve dahi mekânın matematiksel olarak hem kanıtlanması hem de ele geçirilmesini ifade eder. Bu anlamda Teslis için, Hıristiyanlığa sonradan ve buradan girdiği söylenebilir. Dolayısıyla din de geometrik açıdan üçgen üzerinde formüle edilmiştir.

3 Jacques Lacan, Psikanalizin Dört Temel Kavramı, çev. Nilüfer Erdem (İstanbul: Metis Yayınları, 2019), 109. 
yerleştirilen "mesafe"den dolayı bilginin görüye tabi kılındığı entelektüel bir çaba değil midir?" Bilgi sahibi olmanın görme ve gözlemleme şartına bağlandığı ilkesel sosyolojik tutumda, Alberti’nin kanatlı gözünün, bakışta bağımsız olmak isteyen öznenin ambleminin payı ne kadardır? Gözü diğer tüm duyulardan üstün tutan yaklaşımın (okülersantrizm) habercisi acaba perspektif bakışın resme girmesi olabilir mi? (Erwin Panofsky'e göre modern bilimin pek çok alt alanı, perspektif konusundaki çabaların bir sonucu olarak sanat atölyesinden çıkmadır. $)^{5}$ Eğer öyleyse Medusa'yı verdiği cezayla yetinmeyen Athena'nın öldürmek için gönderdiği Perseus'un aynayı Gorgo'nun yüzüne tutunca, kendi bakışının kurbanı yapan yazgı bir form olarak bilim için de geçerli midir? Geçerli ise o halde bilim gibi diğer sanat, din, dil gibi formlara da ayna tutmak gerekmez mi? Görü ile bilginin eşitlenmesi nihayetinde hakikat ile form, düşünce ile imge arasındaki bağlantıyı keşfettiği iddiasındaki Platon'a kadar geriye gitmektedir. Platon, tanımsız, kendi başına ve dağınık maddeler dünyasıyla idea dünyası arasındaki bağlantıyı, onları ancak birtakım sınırlar atfederek bir forma sokmak suretiyle kurabilmiștir. Formların dilinin ise geometri olduğuna karar vermiştir. Perspektif de son tahlilde, nesneler dünyasını onlara form vererek geometrik bir düzen içine yerleştiren, dolayısıyla da anlam bahşeden bir görme rejimidir. Ancak perspektifin kaotik maddeler dünyasını geometri aracılığılla form vererek idealleştirmesi onun keşif değil icat olduğununu akla getirmektedir. Buradan perspektif için bir görme rejimi olduğu kadar aynı zamanda bir hakikat rejimi olduğu söylenebilir.

Panofsky'e göre modernlik büyük oranda perspektifin başarısıdır. ${ }^{6}$ Modernliği de "görme tarzına, kesin olarak doğrusal perspektifle ifade edilen bir mekân kavrayışının hükmettiği çağ"” şeklinde tanımlar. Böylece yeni mekân kavrayışının da perspektifin türediği bağlamdan çıkmış olduğu anlaşılmaktadır. Perspektif resimde mekân, aslında mekân olmayan bir yüzeyde olduğundan, sadece bakışla ve bakış için yaratılır. Resimde mekânın olmasının nedeni, bakışın bir mekâna ihtiyacı olmasıdır. Ayrıca göz ile bakış, özne ile nesne yalnızca durağanlık temelinde çakışabilmektedir. Bu da hareket etmeyen bir mekânı zorunlu kılmaktadır. Zaten mekân hareket etmediği sürece ancak bilgi nesnesi olabilmektedir. ${ }^{8}$

4 Frantz Fanon, Siyah Deri Beyaz Maskeler'de beyaz bir çocuğun eliyle işaret ederek “Anne, bak Zenci!” sahnesinin anlatıldığı ünlü pasajında siyahın "Batılı bakışlar altında" sabitlendiğinden söz eder. "Batılı bakışlar altında parçalarıma ayrılıyorum... Sabitleniyorum." Bk. Frantz Fanon, Siyah Deri Beyaz Maskeler, çev. Cahit Koytak (isstanbul: Encore Yayınları, 2016), 145. Fanon'u hayatı boyunca uğraşmak durumunda bırakan bu (Batılı) bakış, günümüz sosyal bilimlerinde fenomenolojik bir yöntem olarak kabul görmektedir. Gözlemcinin bakışında inceleme nesnesi, her şeyden önce "sabitlenme" ön şartına tabidir.

5 Erwin Panofsky, Gotik Mimarlk ve Skolastik Felsefe, Ortaçağda Sanat, Felsefe ve Din Arasindaki Benzerliklerin İncelenmesi, çev. Engin Akyürek (istanbul: Kabalcı Yayınları, 2014), 42.

6 Tabi bu ifade, perspektifin Rönesans'tan önce, örneğin antik Yunanda resimde, mimaride ve tiyatroda sahne dekorunda kullanılmadığı anlamına gelmez. Perspektif kullanımının ilk kez modernite ve Rönesans'la başlamadığı doğrudur, lâkin Rönesans'la her yerde yayılarak, otorite haline gelmiştir.

7 Erwin Panofsky, Perspektif: Simgesel Bir Biçim, çev. Yeşim Tükel (İstanbul: Metis Yayınları, 2013), 16.

8 Perspektifin çıkışı, gözdeki doğal yansıtmaya dayandırılır ve perspektifin aslında natürel olduğu iddia edilir. Buna göre, göz uzağı küçük ve flu görür anlayışı ile resme ve mimariye aktarımı da bunun üzerinden yapılır. Hâlbuki göz yapısal olarak buna müsait olmadığı gibi, bakışta da bu her zaman mümkün 
Makale, simgesel bir form olarak perspektif üzerinden kentsel mekân poetikasını inceleme konusu yapmaktadır. Bunu yaparken görme ile perspektif, perspektif ile mekân, mekân ile modern din anlayışı arasında bağlantılar kurulmuştur. Bu maksatla çalışmanın birinci bölümünde, perspektif konusu, toplumsal hayat ile formlar arasındaki gergin ilişki çerçevesinde ele alınmıştır. İkinci bölümde ise, perspektifin bir form olarak içinden çıkmış olmasına rağmen hayatın farklı alanlarını düzenleme iradesi tartışmaya açılmıştır. Son bölümde ise, düzenleme pratiğinin neticesinde parsellenen kent mekânında sınırları çizilen dine dair seküler bakış eleștiri konusu yapılmıştır. Dolayısıyla perspektif, çizimde ve resimde sadece bir teknik olmanın çok daha ötesinde düşüncede, görmede, kentin toplumsal ve dinî mekânında modern epistemenin düzenleme pratiği olarak karşımıza çıkmaktadır. Oysaki Antik Yunan'dan önce kadim geleneklerde perspektif biliniyor olmasına rağmen kullanılmamıştır. Bu çalışma, son tahlilde günümüz modern hayatın üzerine bina edildiği modern epistemenin temel parametrelerinin neler olduğunu ve hangi saiklerle oluştuğunu anlama çabasının bir ürünüdür. Bu doğrultuda modern dönem Batılı kent ve mimarinin mekân anlayışını belirleyen birer görme rejimleri olarak perspektif, camera obscura ile bir model olarak modern toplumu şekillendiren panoptik sistem arasındaki bağlantıların izi sürülmektedir. Ayrıca medeniyetlerin kent mekânında kurulduğuna dair düşünce kendisini tarihsel olarak kanıtlamış bir düşüncedir. Herhangi bir dünya görüşünün (Weltanschauung) insan, toplum, tarih, eşya ve evren anlayışı bütüncül olarak ancak bir kent mekânında neşvünema bulur. Özellikle Batı düşüncesinin mekâna olan yaklaşımını toplumsal açıdan analiz etmeye yönelik olan bu çalışma, ayrıca Müslüman mekân anlayışıyla ilgili yorumlardan bir karşılaştırma imkânı sunmayı amaçlamaktadır. Araştırma konusu mimari ve kent yapılanması olunca makalenin tarzı ve yönteminin yapıbozum olması kaçınılmazdır. Bu yüzden olsa gerek Karatani, mimariyi "bir metafor olarak, çeşitli biçimselleştirmelerin gerçekleștiği bir sistem olarak ele alır. Bu anlamda mimari, Batı düşüncesini temellendiren metafiziği kaçınılmaz olarak

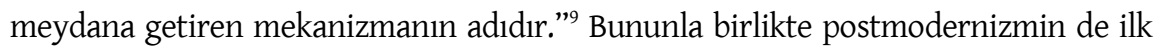
olarak mimaride ortaya çıktığ 1 bilinmektedir. Keza yine bir kavram olarak anlaşılan yapı'nın da mimari bir kavram olduğu açıktır. Bu yüzden Platon'dan yola çıkılarak geliştirilmiş olan düşüncenin altını oymaya çalışan hareketin adııın yapıbozum olması hiç de rastlantı sayılmamalıdır. ${ }^{10}$

değildir. Elbette perspektifin geçerli olduğu anlar vardır ve bunlar da gayet doğaldır. Buradaki sorun gözün her zaman her yerde her nesneye karşı bakışının tek biçim üzerinden ele alınmasındandır. Bu da gözün doğallığını değil tam tersi gözün çoklu farklı görme biçimlerini, tek bir biçim için feda etme, bununla bir dayatma gerçekleştirmeyi ortaya çıkarır. Göz çoğalmaz, bu yolla azalır; çok yönlü çalıştırılmaz, tam tersi tembelleştirilir. Terbiye etme adına köreltilir.

9 Kojin Karatani, Metafor Olarak Mimari, çev. Barış Yıldırım (İstanbul: Metis Yayınları, 2017), 10.

10 Yapı ile mimari ayrımı çok eskiden beridir varolan ve daha çok büyük harfli gelenek taraftarlarınca kullanılan bir ayrımdır. Yapı derken tabi daha çok bina akla gelir ve her ne kadar içinde yine bir ustalık barındırsa da doğal bir ihtiyacı imler. Ancak mimari bir icattır, ihtiyaçtan öte bir anlayışı çağrıştırır. Daha çok ressamla özel anlamda bir sanatçı imgesinin yaratılması gibi, mimari üslup ile de mimar adı altında 


\section{Simgesel Bir Form Olarak Perspektif}

"Perspektif eğitimi ehlileştirmeden başka bir şey değildir."11

20. yüzyılın önemli sanat tarihçilerinden Erwin Panofsky (1892-1968) Simgesel Bir Form Olarak Perspektif" isimli meşhur incelemesinde resimdeki perspektifi "simgesel biçim" olarak tanımlarken, Ernst Cassirer'in bir kavramından yola çıkmıştır. Panofsky, bu eserinde Cassirer'in bulduğu terimin sanat tarihinde de kullanılmasının isabetli olacağını dile getirmiştir. ${ }^{13}$ Nitekim Cassirer' in kitabı Sembolik Formlar Felsefesi başlı̆ını taşımaktadır. Ancak Cassirer'in kendisi, sanatı genel itibariyle simgesel bir biçim olarak görürken, perspektifin adını bile anmaz. Oysaki Cassirer'in düşüncesi bir adım daha ileriye götürüldüğünde, yeniçağ sanatı gerçek anlamda tam da perspektifle birlikte "simgesel biçim" halini almıştır. Zira o dönemin sanatının hem başka kültürlerin hem de Batı'nın Ortaçağ sanatından ayrışması tamamen perspektifin icadıyladır. Perspektif için yalnızca sanatı değiştirmekle kalmayıp, bir kültürü tepeden tırnağa dönüşüme uğratmayı başardığı ileri sürülebilir. Bu açıdan perspektif bir kültür tekniği olarak görülmeye imkân veren bir yaratıma sahiptir. Dolayısıyla sadece sanatın meselesi şeklinde değerlendirilmemelidir. Perspektif, herkesin dünyayı kendi gözüyle algılayabilme hakkının simgesi haline gelmiştir. Bu açıdan perspektif için yeniçağ kültürünü ifade eden "simgesel biçim" in adı olduğu söylenebilir.

"Simgesel biçim", esasında nesnenin (fenomenin) öznel bir biçim ve kategori aracılı̆̆ıla oluşturulduğunu savunan Immanuel Kant'ın düşüncesine dayanmaktadır. Kant felsefesi, felsefi sorunların dilden hareket edilerek düşünülmeye başlandı̆̆ı “dile dönüş" sonrası tarafindan öznel olduğu gerekçesiyle eleştirilse de Kant'in işaret ettiği duyum biçimleri ve sezgi kategorileri dilseldi. Karatani, Modern Japon Edebiyatı üzerine kaleme aldığı Derinliğin Keş̧i isimli eserinde, resim ile edebiyat arasında analoji kurar (ona göre bu analojiyi mümkün kılan unsurlardan biri de perspektiftir) ve resimden edebiyata bakıldığında, modern edebiyata özellik kazandıran öznellik ve kendini ifade etme düşüncesinin, dünyanın "sabit bir bakış açısına sahip bir kimse" tarafından görülmesi durumuna karşllık geldiğini belirtir. Karatani'ye göre sadece nesnelliği değil, öznelliği de üreten aygit geometrik perspektiftir. ${ }^{14}$ Neo-Kantçı filozof Cassirer ise nesnenin öznel bir biçim ve kategori aracillğıyla oluşumuna "simgesel

başka bir fenomen yaratılmıştır. Bunun kökeninde Tanrı'nın mimar olarak görülmesinden, kendilerini Tanrı'nın sevgili kulları olarak telakki eden Yahudi zihniyetine kadar götürülmesi mümkündür.

11 Pavel Florenski, Tersten Perspektif, çev. Yeşim Tükel (İstanbul: Metis Yayınları, 2013), 112.

12 1927'de kaleme aldığı eserinin orijinal ismi Die Perspektive als "Symbolishe Form"dur. Panofsky'nin bu eseri Türkçe'ye Perspektif: Simgesel Bir Biçim olarak çevrilmiştir. Panofsky'nin "sembolik biçim” terimini ödünç aldığ Cassirer'in üç ciltlik eseri ise Sembolik Formlar Felsefesi başlığılla yayımlanmışıı. Makalede her ikisi de aynı anlamda kullanılmıştır.

13 Panofsky, Perspektif: Simgesel Bir Biçim, 24.

14 Kojin Karatani, Derinliğin Keşfi, çev. Devrim Çetin Güven-İnan Öner (İstanbul: Metis Yayınları, 2011), 36. Karatani'nin bu açıklamaları günümüzde bilimin mottosu konumundaki “nesnelliği” sorunlu hale getirmektedir. Zaten makalenin çıkış noktası da, hayat ile form, gerçeklik ile temsil arasındaki gergin ilişkiden doğan nesnelliği tartışlır yapmaktır. 
form" adını vermiştir. Cassirer'e göre gerçeklik kendini formlar olarak gösterdiğinden ancak formlar üzerinden açılanabilir. Sanat, bilim, din, dil birer sembolik formlardır. ${ }^{15}$ Cassirer' in bu görüşleri bir dönem Berlin Üniversitesi'nde seminerlerine katıldı̆̆ı Georg Simmel'i akla getirmektedir. Simmel, hayatın birtakım yapıtlar -sanat, din, bilim, teknoloji gibi- aracılığıyla formlar halinde gerçekleştiğini ve kendisini bu formlarla ifade ettiğini ileri sürer. Bunlar, hayatın yaratım kuvvetini içlerine almak suretiyle hayata form, içerik ve düzen kazandırır. Kendisi formsuz olan hayatın kendisini fenomen olarak gösterebilmesi forma girmesine bağlıdır. Lakin her form, özü gereği, daha ortaya çıktığı andan itibaren, geçiciliği aştığı iddiasıyla hayattan bağımsız bir şekilde geçerlilik ve gerçeklik talep eder. Her form zorla hayata dayatılmış bir şey olarak duyumsanmaya başlayınca, hayat formlardan kurtulmaya çalışır. Dolayısıyla hayat ile formlar arasında gücül bir gerilim devam edegelir. Ama her defasında hayatın hızlı ritmi, iniş çıkışları, sürekli yenilenişi, bunlardan bağımsız olan formlara baskın gelir. Hayat bir yandan durmaksızın formlar yaratırken, diğer yandan da durmaksızın formları yıkar. Bu formlarda, hem kendilerinden uzaklaşan yaratıcı hayatı taşıyan, ama bir süre sonra kuşatamaz oldukları paradoks bir durum söz konusudur. "illk oluşma anlarında hayatla uyumlu olabilirler, ama hayat kendi evrimini sürdürdükçe, bu formlar katılaşıp sabitleşmeye başlar, hayata yabancı hatta düşman hale gelirler. Hayat ise kendisine bağımlı olan herhangi bir şeyin egemenliği altına girmeye direnir, hatta egemenliği altına girmeyi toptan reddeder."16

Form ile hayat arasındaki paradoksal gelgitler, "Felsefenin somut konulara dönmesini sağlayan" Simmel'e göre dinsel form için de geçerlidir. "Dinsel hayatın tikel bir formu, başlangıçta o hayatın doğasıyla ve enerjileriyle gayet uyumluyken, giderek dışsal bir nitelik kazanır, belli sınırlar içine girerek esnekliğini yitirir. o zaman, o an tezahür ettiği şekliyle dinsel itkinin kendiliğinden dinamizmini barındırabilen yeni bir form tarafından bertaraf edilir. Zamanı geçen formun yerini alan yeni form da çeşitli inanç ilkeleriyle yine dinsel bir formdur." ${ }^{17}$ Lâkin Simmel, her ne kadar dini diğer formlar gibi bir form olarak düşünse de hayatı dolaysızca yaşama noktasında dine iyimser yaklaşmaktadır. Simmel, dini "Hayat senfonisi içinde tek bir ezgi değil de bütün bir senfoninin anahtarı gibi"18 düşünmektedir. Sözünü ettiği "Her şeyi kapsayan, kendiliğinden hayat süreci olarak dinselliktir. Sahip olma değil, olma halidir; bir inanç, bir nesneye sahipse din adını alır, ama burada inanç hayatın kendi akışı

15 Ernst Cassirer, The Philosophy of Symbolic Forms Volume I: Language, trans. Ralph Manheim (New Haven \& London: Yale University Press, 1980), 78.

16 Georg Simmel, Modern Kültürde Çatışma, çev. Tanıl Bora vd. (İstanbul: İletişim Yayınları, 2017), 56-57.

17 Simmel, Modern Kültürde Çatışma, 76.

18 Simmel, Modern Kültürde Çatışma, 76. Simmel'in dine dair argümanlarını formülleştirecek olursak şu söylenebilir: Din hayattır. Makalenin yazım gerekçelerinden, belki de yazmaya icbar eden temel unsur, kurulan ilişkiye bağlı olarak farklılaşmakla birlikte sanat, bilim, felsefe, sosyoloji, edebiyat ve din gibi hayatı anladığı ve de anlattığı iddiasındaki bu formların hayat karşısında birer "form" olmaları, hayata sınır koymaları, başlangıçta sadece form iken, bir an sonra, gerçeklik iddiasında bulunmaları, dolayısıyla hayatla insan arasına mesafe koymaları sebebiyle yaşadıkları ve yaşattıklari sorundur. 
içinde yer alır. İhtiyaçlar artık dışsal bir şey tarafından karşılanmaz... Hayat dolaysız bir dinsel ifade tarzı arar." ${ }^{19}$

Hayat ile formlar arasındaki gelgit ilişki, Ben ve Ben-değil arasındaki Kantçı bağlama oturtulabilir. Nitekim perspektif içindeki bir resim yalnızca bir mimesis (taklit) egzersizi değil, aynı zamanda dünyayı belli bir tarzda düzenleme arzusunun dışavurumudur. İçinden çıktıkları hayata rağmen, hayata galebe çalmaya çalışan formların bu durumu, Cassirer' in diliyle söyleyecek olursak, "her bir sembolik alanının 'içerisi' ile 'dışarıss', Ben ile dünya arasındaki kendi özgül ve indirgenemez ilişkisini tasarlamakla kalmayıp, fiilen yaratmasıdır." ${ }^{20}$ Cassirer'in bu dilini Panofsky ile perspektife uyarlayacak olursak, perspektif için "doğası gereği iki kenarlı bir silah" tanımlaması yapılabilir. Panofsky'e göre perspektife dayalı bir resim varlı̆̆ını, insan ile dünyası arasındaki nesneler arasında zorunlu "mesafeye" borçludur. Ben ile ben-olmayan arasındaki kategorik ayrımı, başka bir deyişle öznellik ile nesnellik arasındaki metafizik karşıtlığı perspektif sisteminde "mesafe" kavramı ile uzlaştırılır. Birincisi gören gözdür, ikincisi görülen nesnedir, üçüncüsüyse aradaki mesafedir. Dolayısıyla perspektifin tarihi, aynı ölçüde hem mesafeyi ve nesnelliği doğuran gerçeklik hissinin hem de mesafeyi inkâr eden insanın iktidar mücadelesinin bir zaferi olarak anlaşılabilir. Keza aynı ölçüde hem dış dünyanın sabitlenmesi ve sistematikleştirilmesi hem de ego alanının genişlemesinden bahsedilebilir. Perspektif resminde göz ile şeylerin arasına -özne ile nesne arasına, nesneyi nesnelleştiren ve özneyi de öznelleştirenmesafe konması, günümüzün kendisine nesnelliği ilke edinmiş araştırmacı bilim insanını anımsatmaktadır.

Wittgenstein'n, gerçekliğin dil aracıllğıyla yeniden üretildiğine dair görüşü, formun hakikat istencini göstermesi açısından güzel bir örnektir. Wittgenstein'ın bilgiye ilişkin resim teorisi bu noktada ilginç bir paralellik sunmaktadır. Wittgenstein, arkadaşlarından birine, resim kuramııı oluşturan ilk düşüncenin, I. Dünya Savaşı boyunca Avusturya ordusuna hizmet ederken yaşadığı bir deneyim sırasında aklına geldiğini söylemiştir. Meydana gelen bir trafik kazasını bir şema ya da plan yardımıyla betimleyen bir gazete okur ve o anda, bu simgesel tasvirin bir önerme olduğunu ve buna karşıllk olarak, önermenin bir tür çizim ya da resim olarak değerlendirilebileceğini düşünür. Bir önerme yalnızca önermede bulunanın gerçekliğini onaylar; çizgisel perspektif gibi, seyredeni yüceltir. Her şey onları düşünen kişiye göre var olur. "Dünyanın benim dünyam olduğu, kendini şurada gösterir ki, dilin (yalnızca benim anladığım dilin) sınırları, benim dünyamın sınırlarını imler."21

19 Simmel, Modern Kültürde Çatıșma, 77.

20 Cassirer, The Philosophy of Symbolic Forms Volume I: Language, 91.

21 Ludwig Wittgenstein, Tractatus-Logico Philosophicus, çev. Oruç Aruoba (İstanbul: Metis Yayınları, 2013), 135. Martin Jay, Wittgenstein'ın resim teorisine benzer şekilde, görme ile dilin karşılıklı bağımlılığının nerelere vardığının bir göstergesi olarak, anıtsal çalışması Downcast Eyes: The Denigration of Vision in Twentieth-Century French Thought'un ilk paragrafında, tam yirmi bir görsel metaforun adını anar. Bk. Martin Jay, Downcast Eyes: The Denigration of Vision in Twentieth-Century French Thought (Berkeley and Los Angeles: University of California Press, 1993), 1. 
Doğrudan Cassirer'den esinlenerek yazdı̆̆ bir denemesinde Nelson Goodman, hem Wittgenstein hem de Cassirer geleneğindeki bu damarı irdeler: "Ĕ̆er size dünyayı sorarsam, onun bir ya da daha fazla referans düzlemine uyduğunu söylememi önerebilirsiniz; ama onun bütün düzlemlerden nasıl ayrı olduğunu bana anlatmanızı istersem, ne anlatabilirsiniz bana? Tarif edilen şey ne olursa olsun, tarif etme yollarıyla sinırlıyı. Bizim evrenimiz, deyim yerindeyse, bir dünya ya da dünyalardan ziyade bu tarif yollarından oluşur." ${ }^{22}$ Belli ki Goodman'ın da dikkatini çekmiş olan perspektif yapısı, bilhassa insanın sembolize etme, dünyalar içinde dünyalar çerçeveleme eğiliminin göstergesidir. Anlaşılır şekilde bütün temsil araçları, özellikle de çizgisel perspektif olanı bizi sürekli dünyada konumlandırmaktadır. Temsiliyet belli ki insanın hayatta kalabilmek için başvurduğu varoluş tarzıdır. Bundan olsa gerek Michael Ann Holly, formun yokluğunda kaos tehdidi karşısında yılmış, temsiliyete teslim olmuş görünüyor, beyanı oldukça fasih: "Açıcçası onlarsız gözden kaybolurduk."23

Sorunun temsile ve temsil krizine evrildiği tam bu noktada, Rönesans insanının ifade ve temsil etmek gibi iki farklı etkinliği tek bir göstermek (mostrare) fiili ile karşladığını hatırlatmak anlamlı olacaktır. Latince bir sözcük olan perspectiva da açık seçik görmek, olması gerektiği netlikle görmek anlamına gelen perspicere'den türetilmiştir. ${ }^{24} \mathrm{~Pa}$ nofsky'e göre, bir önceki Skolastik dönemin temel ilkesi de aydınlatmak, açıkça göstermek ve açıllı̆̆a kavuşturmaktır (manifestatio). ${ }^{25}$ Bu dönemi karakterize eden, sonrasında bütün bir Batı düşüncesini esareti altına alacak olan "açık seçik hale getirme tutkusu”,

22 Nelson Goodman, Ways of Worldmaking (Indiana: Hackett Publishing, 1978), 2-3.

23 Michael Ann Holly, Panofsky ve Sanat Tarihinin Kökleri, çev. Orhan Düz (İstanbul: Dedalus Yayınları, 2016), 224.

24 Panofsky, Perspektif: Simgesel Bir Biçim, 61. Perspektif, iki boyutlu bir yüzeyde cisimleri derinlik yaratmak suretiyle üç boyutlu gösteren tekniğin adıdır. Nesneler bizden uzaklaştıkça küçük ve flu, bize yakınlaştıkça büyük ve net görünür. Hâlbuki bazen uzaktakini net, önümüzdekini ise göremediğimiz anlar olur. Demiryolu rayının her iki tarafında sıralanan telefon direkleri bir noktadan sonra birleşir, aslında birleşmez, birleşir görünür. Bizler nesneleri dışbükey aynaya yansıyan görüntüde olduğu gibi bombeli görürüz. Esasında tepegözler gibi tek bir sabit gözle görmemiz sözkonusu değildir. Panofsky'e göre Rönesans kuramcılarının sorunu, retina görüntüsünün biz düzlemde değil de içbükey bir yüzeyde algılanan şeylerin şekillerini gösterdiğini hesaba katmamalarıdır. Düzlem perspektifi düz çizgileri düz olarak yansıtırken bizim görme organımız onları eğri olarak algılar. Dolayısıyla perspektif tekniğiyle yapılan bir resimde idealleştirmeden söz edebiliriz. Göz aynı zamanda ters görür, beyinde düzeltilir, dolayısıyla göz doğal bir camera obscura'dır. Bu konu camera obscura bahsinde ayrıntılı olarak ele alınacaktır. Perspektif kuramcısı Alberti bir tablo anlayışı yaratmış ve bu anlayış, en azından soyut resmin ortaya çıktığı döneme kadar, bütün Batı'da hâkim olmuştur. “Öncelikle nerede resim yapacağımı düşünürüm. İstediğim büyüklükte, düz açıları olan bir dörtkenar çizerim ve bunu, resmini yapacağım şeyleri izlediğim açık bir pencere olarak görürüm." Bk. Alberti'den aktaran France Farago, Sanat, çev. Özcan Doğan (Ankara: Doğu Batı Yayınları, 2017), 73. “Çerçeve bu açık pencerenin açıldı̆̆ı nokta olacaktır. Tuval üzerinde ressam pencere aracılığıyla görülen şeyleri yeniden üretir; eğik çizgileri bir ya da birden fazla kaçış noktası (telefon direkleri örneğinde olduğu gibi direklerin birleştiği yer) halinde keserek perspektif kuramını uygular. Alberti görsel bir piramit kurgular; bu piramidin en üst noktası ressamın ya da izleyicinin gözüdür; en alt kısmı ise resmin destek noktasıdır. Destek noktası üzerinde (tuval, pano ya da duvar) tablonun perspektif alanı başlar. Perspektif tablonun düzenlenmesidir." Bk. Farago, Sanat, 73.

25 Panofsky, Gotik Mimarlik ve Skolastik Felsefe, 26. 
düşünen tüm kafalarda zihinsel alşskanliğa ${ }^{26}$ dönüşmüştür. Bugün de herkesin bildiği üzere başlıca akademik çalışmaların, özellikle de tezlerin yapısının, bir içindekiler listesinde gösterildiği şekliyle bölümler ve alt bölümler şemasına göre düzenlenmesinde köken olarak Skolastik dönemin summa tekniği yatmaktadır. Thomas Aquinas'in aynı zamanda Trinitaryanı sembolize eden Summa Theologiae's1, summa tekniğine en güzel örnektir.

Kendilerinde, düşüncelerinin düzenini ve mantığını elle tutulacak, gözle görülecek kadar açık bir biçime sokma zorunluluğu hissetmeleri, başka türlü söylersek kesinlik ve sabitlik arayışı, toplumsal hayatın akışkan ve eşsiz karakteri karşısında duyulan korkudan kaynaklanmaktadır. Nihayetinde kaos sürdürülebilir değildir. Kendince hayatını devam ettirebilmesi, düzenlemesine, tektipleștirmesine, forma sokmasına, mimari tabirle yapısal bir çerçeveye oturtmasına bağlıdır. Bu sayede gözetime ve denetime açı hale gelmesiyle dünya, karşıdan bakılabilir ve ehlileştirilebilir bir uzama dönüştürülmüş olmaktadır. Berger ve Luckmann'a göre insanoğlu, hayat alanının her ayrıntısını yapılandıran bütüncül bir nomos'a gerek duymaktadır. ${ }^{27}$ Berger ve Luckmann'ın yaptığı esasında, kutsal bir çatının tüm insan ilişkilerinin zorunlu bir çehresi olduğuna inanarak, bizi kaos olasılığıyla yıldırmaktan başka bir şey olmadığı iddia edilebilir.

Sözcüklerdeki ortak anlam açıkça göstermek, açık seçik hale getirmek olunca göz merkezli bu dünya görüşünün kültürel olarak dünyayı gizemden arındırmak şeklinde kodlandığı söylenebilir. İronik bir şekilde, dünyayı büyüden arındıran perspektifin icat edildiğinde insanları en çok büyüleyen de dünyanın gizemli ve geçici yansımalarının birdenbire kalıcı bir resme dönüşerek sabitlenmesi olmuştur. "Dünyanın büyüden arındırılması" süreci, "her öznenin aynı bakış açısıyla sahip olabileceği nesnel görüşü ifade" ${ }^{28}$ ettiği iddiasındaki perspektifin icadıyla koşuttur. Rönesans öncesi dini ve toplumsal dünyanın tikel ve hiyerarşik yaklaşımını ortadan kaldıran, günümüz bilimsel anlama yetisinin nesneleşmesini simgeleyen gören öznenin evrenselliği, kültürel bir teknik olarak perspektifin yeniden keşfi sayesinde mümkün olmuştur. Görme biçimlerini dört yüzyll boyunca sürdürecek olan bu yapı, sanat ve mimaride köklü bir kopuş anlamına gelmekteydi. Bu, Rönesans'in başarısıydı (Andre Bazin'e göre günahı) ${ }^{29}$ Heidegger, Nietzsche’nin Tanrı Öldü Sözü ve Dünya Resimleri Çağı’nda, yeniçağın temel olgusunun dünyanın resim olarak ele geçirilmesi olduğunu iddia eder ve "Yeniçağ ilk kez kendi tarihinin en kararlı, belki de en kalıcı yeni bir bölümüne

26 Panofsky, Gotik Mimarlık ve Skolastik Felsefe, 31. Panofsky'nin burada kullandığı zihinsel alışkanlık ifadesi Bourdieu sosyolojisinde anahtar kavramlardan biri olan habitus'a karşılık gelmektedir. Bourdieu, kavramı Panofsky'nin bu eserini Fransızca'ya çevirdikten sonra kullanmaya başlamiştır.

27 Peter L. Berger-Thomas Luckmann, Gerçekliğin Sosyal İnşası, Bir Bilgi Sosyolojisi Incelemesi, çev. Vefa Saygın Ögütle (Ankara: Atıf Yayınları, 2018), 154-155.

28 Farago, Sanat, 149.

29 "Perspektif Batı resminin ilk günahıydı." Bk. Andre Bazin, Çağdaş Sinemanın Sorunları, çev. Nijat Özön (Ankara: Bilgi Yayınevi 1966), 34. 
girer." ${ }^{30}$ diye de ekler. Gerçekten de perspektif dediğimiz resim icadı, görmenin tarihinde bir devrim yaratmıştır. Bakış, sanatın hakemi yapılınca, Heidegger'in ifadesiyle dünya resim olur. ${ }^{31}$ Bir izleyicinin dünyaya çevirdiği bakış ilk kez perspektif sayesinde ortaya konur. Aslında perspektif için dünyayı dünyaya bakışa dönüştürdüğü de söylenebilir. Bireyselci bir dünya, dünyaya kendi sabit konumundan bakan bir izleyiciyi gerektirir; "dünyada olmak", dünyada olmak ayrılış, kopuş, Âdem’in Tanrısından kendi hakikati uğruna kopması demektir. Bu kopuşu anlatan en iyi imge, aynı zamanda Rönesans ruhunu temsil eden imgelerden biri olan Michelangelo'nun Sistina Şapelinin "tavan süslemelerinde yer alan Âdem imgesidir. Yaratılış düşüncesinde Tanrı'dan geldiği halde O'ndan kopup kurtuluyor şeklinde gösterilen insanın üstün geldiği bu fresklerde"32 bir iç-güç ifadesi kendini gösterir. Tanrı'nın ve Âdem'in parmakları başlangıçtan gelen bir olma haliyle birbirine dokunuyor ama daha sonra birbirinden ayrılıyor, ayrılması gerekiyor, çünkü yaratılan insanın özgürlüğe kavuşması ancak buna bağlı. "Dünya'ya bakmak”a dönüştü. Bununla birlikte göz bakışın dünyayı kontrol etmesini sağladı. Perspektif resmiyse bakışın kendi kendini tasvir ettiği simgesel bir ayna haline geldi. ${ }^{33}$ Böylece perspektif ile izleyicinin resmin önüne konmak suretiyle ayrıcalıklı bir konuma erişmesi sağlanmış oldu. "Resim mekânında neyin önde, neyin arkada ve neyin uzakta neyin yakında olduğunu belirleyen bu sanatsal yöntem, kartezyen egemenliğin uzantısıdır: onun sayesinde dünya ehlileştirilmekte, karşıdan bakılabilir ve denetlenebilir bir mekâna dönüşmesi sağlanmış olmaktadır. Böylece bakışı tatmin etmekte, bakana egemenlik bahşetmektedir." ${ }^{34}$

\section{2. İdeal Kentin Mekân Poetikası}

Rönesans, Batı dünyasında mekân konusundaki görüşlerin köklü bir biçimde yenilenmesine tanık olmuştur. Özellikle bu dönemde gerçekleştirilen coğrafi keşifler Batılının hiç alışık ve aşina olmadığı türden dış dünya hakkında baş döndürücü bir bilgi akışı sağlamaktaydı. Bu bilgilerin bir şekilde içselleştirilmesi ve temsil edilmesi

30 Martin Heidegger, Nietzsche'nin Tanrı Öldü Sözü ve Dünya Resimleri Çağı, çev. Levent Özşar (Bursa: Asa Yayinları, 2001), 82.

31 Shakespeare'in daha sonraları “dünya bir sahnedir." diye çevireceği teatrum mundi tabirini Richard Sennett'in Ten ve Taş'ta aktardıklarına göre Romalılara borçluyuz. Romalıların teatrum mundi deneyimi, görünüşlere birebir biçimde inanmak gibi bir tavra dayalıydı. Roma amfiteatrında sahnelenen gösterilerde mitik hikâyeler onu fiilen gerçekleştirerek geliştirilmekteydi. Temsil gerçekliğin yerini almaktaydı adeta. Aziz Augustinus'a göre Teatrum mundi'nin sahip olduğu güç Tanrı inancını bile bastırabilirdi. Bk. Richard Sennett, Beden ve Taş, Batı Uygarlığında Beden ve Şehir, çev. Tuncay Birkan (İstanbul: Metis Yayınları, 2014), 88. Bu durum, Foucault'nun tabiriyle, "görünürlüğün tuzağına” yakalanmaktan kendini kurtaramayış Roma düsturunu akla getirmektedir: "Bak ve itaat et." Bu arada theory ile theatral' in aynı kökten türediğini hatırlatmak gerekiyor. Ayrıca temsil ile gerçeklik arasındaki gergin ilişki dilde de geçerlidir. Bizler kavramları yarattıktan sonra onların kendi icadımız olduğunu unutur adeta hakikat olduklarına inanmaya başlarız. Çünkü dil kendi gerçekliğini dayatır.

32 Farago, Sanat, 69.

33 Hans Belting, Floransa ve Bağdat, Doğu'da ve Batı'da Bakışın Tarihi, çev. Zehra Aksu Yılmazer (İstanbul: Küy Yayınları, 2017), 167-168.

34 Zeynep Sayın, İmgenin Pornografisi (İstanbul: Metis Yayınları, 2013), 16. 
gerekiyordu. Keşifler, sonu olan ve potansiyel olarak bilinebilir bir yerkürenin varl1ğını imlemekteydi. Zaman içerisinde coğrafya hakkında elde edilen bilgiler birer meta haline geldi. "Servet, güç ve sermaye birikimi, mekân konusunda kişiselleşmiş bilgiye ve mekân üzerinde bireysel denetime bağlanmaya başladı." ${ }^{35}$ Ancak Batı dünyasının mekân anlayışındaki devrimi gerçekleştirebilmesi için perspektifin temel kurallarının Floransa'da Brunelleschi ve Alberti tarafından işlenmesini beklemesi gerekiyordu. Hümanistlerle olan ortak bağına geçmeden önce perspektifin yeni bir icat değil, eski bir ilim olan optik teorisine dayandığına dair tarihi bilgileri vermek gerekiyor. Öncelikle belirtmek gerekir ki, geometrik perspektifin Rönesans'ta icat edildiği bir efsanedir. Gerçekte perspektif, Avrupa'da daha Ortaçağda bile Arap teorisi olarak biliniyordu ve Latince'ye perspektiva kavramıyla çevrilmişti. Matematikçi İbnü'l-Heysem'in (965-1040) başyapıtı Kitabu'l-Menazir, 1572'den sonra Yunanca bir kavram olan ve ışığı inceleyen algı öğretisi olarak bilinen Optik başlığıyla yayımlanmaya başlamıştı. Ondan önce İspanya'da Perspectiva başlı̆̆ıyla tahminen 1200 yılında Latinceye çevrilmişti. ${ }^{36}$ íbnü'l Heysem, 1 şı̆̆ı̆ı gözden nesneye değil, nesneden göze geldiğini ortaya koymak suretiyle zaten, o zamana kadar gelen ezberleri bozmayı başarmıştı. Ayrıca Marx'ın ideolojilerle arasında işlevsel olarak benzerlik kurduğu, fotoğraf makinesinin ${ }^{37}$ prototipi camera obscura (karanlık oda) deneyi Heysem'e aittir. Ancak, sadece askeri sahada kullanmaya taraftar olan İbnü'l Heysem için ışık teorisinin Batı'nın elinde resim teorisine dönüşmesi kabul edilemez bir durum olsa gerektir. Zira Arap dünyası için göz; yanıltabilen, algı işlevini ancak içsel duyular sayesinde tam olarak yerine getirebilen bir organ olarak kabul görmüștü. Şüphesiz Batı ile Doğu arasındaki farkllı lk bundan ibaret değildir. Örneğin geometrinin Batı'da gelişmesi dikkate şayandir. ${ }^{38}$ Deneyleriyle ve karanlik odayı (el-beytü'l-muzlim) icat etmesiyle modern fen bilimlerinin öncüsü olan İbnü'l-Heysem, Euklides ve Ptolemaios'u yepyeni bir temele oturtmuş, Kepler ve Galilei'yi derinden etkilemiştir.

Işık teorisinin görme teorisine dönüşmesiyle ${ }^{39}$ hayat bulan perspektifin, Hans Belting'in yazdıklarından, Batı sömürgeciliği ve Hıristiyan misyonerliğiyle olan tarihine de bir göz atmak gerekiyor. Bu süreçte diğer kültürlerin görme alışkanlıklarının hiçe sayılarak, perspektifin bir sömürge aracı olarak zorla dayatıldığı anlaşılmaktadır.

35 David Harvey, Postmodernliğin Durumu, Kültürel Değişimin Kökenleri, çev. Sungur Savran (ìstanbul: Metis Yayınları, 2014), 274.

36 Belting, Floransa ve Bağdat: Doğu'da ve Batida Bakışın Tarihi, 34.

37 Fotoğraf makinesinin icadının kanonik sosyolojide kurucu olarak kabul görmüş olan Auguste Comte'un Pozitif Felsefe Dersleri’ni yazdı̆̆ yıllara denk gelmesi, sosyolojinin özerk bir disiplin olarak Batılı görme kültürünün gölgesi altında şekillendiğini göstermek açısından önemlidir.

38 Burada Yunan aklının geometriyi, düşünce ve dolayısıyla dilin resimsel karşıl l̆ğ olarak geliştirdiklerini söylemek durumundayız. Kastedilen elbette ki Öklid geometrisidir. Öyle ki Batı düşünce ve sanatı her ne kadar perspektif biçimi İbnü'l-Heysem'in Kitabu'-Menazır'na borçlu olsa da Yunan tiyatro sahneleme biçimlerinde bunun ilk izlerini görmek mümkündür. Aynı zamanda meşhur Romalı mimar Vitruvius'un tapınaklar inşa ederken özellikle sütunların dizilme biçimini bu perspektif eğilimleriyle yaptığı bilinmektedir.

39 Bu dönüşümün nasıl gerçekleştiğine dair daha ayrıntılı bilgi için Hans Belting'in Floransa ve Bağdat: Doğu'da ve Bati'da Bakışın Tarihi isimli eserine bakılabilir. 
Cizvitlerin yeni Hıristiyanlar kazanmak amacıyla 1601'de Pekin'de kurdukları kütüphanede on dokuz perspektif kitabını da yanlarında götürdükleri bilinmektedir. Japonya'da yerli sanatçıların perspektif eğitimine yönelik ilk atölyeler 1501-1614 yılları arasında kurulmuştur. Perspektif resmi bir başka sömürge ülkesi Hindistan'da da sömürgeci eğitimin temel taşıyıcılarından biri olmuştur. Anlaşılan o ki, uygarlık yükünü sırtladı̆̆ına kendini inandıran "Beyaz Adam"a göre perspektif, doğal görme biçiminin normuydu ve gerçekçiliği, modernliğin nimetlerini sömürgelere de getirecek olan ilerlemeyi temsil ediyordu. Oysaki örneğin bir "Ortaçağ sanatçısı, gözünün önünde gördüğünü tek bir toplu gözlem açısından değil, etrafında dolaşarak, çok farklı açılardan yapısını hissederek, neredeyse dokunarak algıladıklarını gösterirse inandırıcı biçimde iletebileceğine inanıyordu." ${ }^{40}$

Perspektif kaideli harita ve resimlerde elde edilen sabit bakış açısı idealize edilmiştir; her yerde aynı, homojenleștiren, evrensel bir göz anlayışı esastır. Bir tür makro Tanrısal gözdür. "Soğuk geometrik" ve "sistematik" bir mekân duygusu yaratır. Batı kültüründeki geometri tasarı geometrisidir ve resimlerin temelini oluşturur. Bu tasarım geometrisinde, "Cisimler kendi büyüklüklerine göre değil, bakıştaki büyüklüklerine göre belirlenir. Bir şeyin gözümüzden ne kadar uzakta olduğunu bilirsek, biçimini ve boyutunu da hesaplayabiliriz. Cisimlerden, ancak mekânda hesaplanabilen bir yerde olduklarında emin olabiliriz. Bu yanıltabilen göze karşı kazanılan bir zafer gibi düşünülmüştür." "'i İlk başlarda doğa yasasıyla uyumlu bir hissiyatla Tanrı'nın geometrik bir biçimde düzenlemiş olduğunu düşündükleri evren içinde insana sorumluluk duygusu veren bu yeni bakış açısı, zaman içinde Tanrı'nın kudretini yansıtmak üzere değil, bilinçli bir irade ile donanmış özgür ve aktif bir birey olarak İnsan'ın özgürlüğünü kutlamaya ve kolaylaştırmaya hizmet için kullanılmıştır. Modern düşüncenin ilk atılımı olarak doğa üzerindeki hâkimiyet insanın özgürleşmesinin öncelikli zorunlu koşulu olarak kabul görmüştür. Perspektivizm ile bireycilik arasındaki bağ önemlidir.

Rönesans'ın mekân mefhumunda yarattığı devrim pek çok bakımdan Aydınlanma düşüncesinin kavramsal temellerine -"bilimsel tahmin, toplumsal mühendislik, rasyonel planlama, rasyonel toplumsal düzenleme"- zemin hazırlamıştır. Modernleşme projesine göre mekânın doğal bir olgu olarak düşünülmesi, mekân üzerinde hâkimiyet kurmayı ve onu rasyonel bir biçimde düzenlemeyi kaçınılmaz kılmıștır. Böylelikle artık toprak üzerinde özel mülkiyet iddia etmenin ve mekânın alınabilir ve satılabilir meta olmasının önünde hiçbir engel kalmamış oldu. Zira mekânın "atomizasyonu" ve parçalanması, denetim altına alınması ve düzenlenmesinin tek yoludur. Mekânın Aristo'ya uygun bir şekilde bir “kap” olarak değerlendirilmesi, dolayısıyla düzenlenmeye ihtiyaç duyması, daima toplumsal iktidarın ifadesini bulmasına aracı olan çerçevenin yeniden düzenlenmesi anlamına gelmektedir. Ayrıca bir gelişme de ulusallaşma sürecine ilişkindir. Ulusal ve yerel kimliklerin inşasına

40 Samuel Edgerton, The Renaissance Re-discovery of Linear Perspective (New York: Harper and Row, 1976)'dan aktaran Harvey, Postmodernliğin Durumu, 272.

41 Belting, Floransa ve Bağdat: Doğu'da ve Batı'da Bakışın Tarihi, 41-42. 
yönelik kavrayışta, harita sayesinde sağlanan bütünsel bakış açısının katkısından söz edilmektedir. ${ }^{42}$

Rönesans dönemi sanat tarihçisi Baxandall, 15. Yüzyllda Sanat ve Deneyim isimli çalışmasında perspektifin toplumsal tarihini araştırır. Baxandall, Rönesans'a egemen olan ölçme kültürü ile kapitalistleşen ekonomi arasında kurduğu ilişkide perspektifi, bu ölçüm kültürüne dâhil eder: “15. yüzyıl Floransa'sında ortaya çıkan kapitalist ekonomi çerçevesindeki ticaret ve bankacıllk girişimleri ile bunlara koşut olan siyasal rejimler, çağdaş bir kültürel zihniyet ve sanatsal himaye düzeniyle iç içe örgütlenmişlerdir. Bu zamandaki en geçerli beceriler hep ölçmeyle ilgilidir." ${ }^{\prime 3}$ Ölçüm her alanda hükmetmek için vardır. Bir düzenleme pratiği olarak değerlendirebileceğimiz dakik zaman ölçüm aletleri ve doğru çizilmiş haritalar, Aydınlanmanın dünyanın nasıl örgütlenmesi gerektiği konusundaki vizyonunda müphemliğin giderilmesine hizmet eden temel araçlar olmuştur. "Bütün bu düzenleme pratikleri; hâkimiyeti altına alma, parselleme, ihata etme, üzerinde denetim kurma ve ehlileştirme amacını matuftur. İzaha muhtaç, boşlukta kalmış hiçbir şeyin olmaması gerekliliği temel prensiptir. Bütün bu episteme nihayetinde, dünya hakkındaki bilgiyi tek bir sistematik bütün içinde organize etmek için gösterilen benzeri görülmemiş bir arzu ve gayretin ürünüdür." ${ }^{\prime 4}$ Perspektife de sanatın ölçüldüğü bir yöntem olarak tanrısallık atfedilmiştir. Perspektif sonrasında dolaşıma sokulan kronometre ile zamanın, kadastro ile doğanın, harita ile de yeryüzünün ölçülmeye başlanması, birbirinden ayrı düşünülecek bağımsız kategoriler değildir. Ayrıca, din ile sanatı buluşturan geometrik düzen, perspektif kuramcısı Alberti'yi, doğanın doğru bir biçimde tasvir edilmesine olanak veren matematiksel sisteme paralel bir ahlaki düzen yaratmaya sevk etmiştir.

İmgelerin alınabilir ve satılabilir birer meta değeri taşır hale gelmesi, perspektifin ve aynı zamanda camera obscura'nın icadıyla koşuttur. Öyle ki camera obscura perspektifle birlikte Yeniçağa özgü görme biçiminin ve gözlemci ile dış dünya arasındaki sergilenen ilişkinin taşınabilir hale geldiği bir cihazdır. Karanlık ve kapalı bir iç mekâna küçük bir delikten ışık girdiğinde, deliğin karşısındaki duvarda ters bir imge oluşacağı iki bin yıldır bilinmekteydi. Ama dışarıyı gözlemlemek isteyen kişinin ancak 16. yüzyılın sonlarından itibaren küçük karanlık bir odaya oturmaya ve dışarının imgelerini bir mercek yardımılla düz olarak görmeye başlamış olması, her şeyin ötesinde artık yeni bir öznellik modelinin başladığına işarettir. Özneyi nesneden, içeriyi dışarıdan ve görme eylemini gözlemcinin fiziksel bedeninden ayrıştıran bu alet, Descartes'e göre dış dünyanın gerçek yani perspektifsel var oluşunun kanıtıdır: “İnsanı tek bir delik hariç tümüyle kapatılmış bir odaya koyun ve deliğin önüne bir mercek yerleştirin. Ondan belirli bir mesafe uzaklığa... ışığın yansıyacağı... boş beyaz bir perde

42 Harvey, Postmodernliğin Durumu, 281.

43 Michael Baxandall, 15. Yüzyılda Sanat ve Deneyim, Stilin Toplumsal Tarihine Giriş, çev. Zeynep Rona (İstanbul: İletişim Yayınları, 2015), 157.

44 İrfan Kaya, "Sosyolojik Düşüncede Avrupa-merkezcilik, Ötekileştirme ve Oryantalist Söylem Üzerine Post-kolonyal Bir Okuma ve Eleştirisi”, Cumhuriyet İlahiyat Dergisi 21/3 (Aralık 2017), 1997. 
gerin. Delik, gözbebeğine dönüşür... ve... dışarıda var olan nesnelerin doğaya uygun, yani perspektifsel olarak... yeniden elde edildiğini görürsünüz." ${ }^{45}$ "Dış dünyayı bir yandan özel mülke ve tabloya dönüştüren ve gözü onun maliki ilan eden camera obscura, diğer yandan akıl için olduğu gibi, gözün yolunun da bir olduğunu vurgulamaktadır." ${ }^{46}$ En nihayetinde bir alet olan camera obscura'nın gücü, verdiği görüntünün, gerçekliğin hakiki görüntüsü olduğu yanılsaması yaratmasındadır. Gözün gördüğüyle hakikatin bir ve aynı şey olduğu anlayışı, Yeniçağa özgü bu yeni bilgiden kaynaklanır." ${ }^{27}$ Leibniz terminolojisiyle camera obscura'nın kavramsal yapısı da sınırlı (monadik) bir bakış açısı ile aynı zamanda kaçınılmaz hakikatin uzlaştığı bir koşutluğu taşımaktadır. Leibniz'e göre camera obscura edilgen ve yalnızca almaya göre tasarlanmış bir alet olmayıp algılanan fikirleri belirli bir yapıya sokabilme konusunda da içkin bir yetiye sahiptir. ${ }^{48}$ Dolayısıyla söz konusu aygıtların hem doğayı hem de insanı yadsıdığını görmek hiç de zor değildir. Her şeye rağmen camera obscura Araplar, İranlılar ve Bizanslılar açısından, hakikatin doğru imgesini vereceği yerde hakikatin ele geçirilemeyeceğini kanıtlayan bir buluştur. Bu iki dünya görüşü arasındaki farklılık, her şeyden önce aletlerin, görme biçiminde olduğu gibi, kültürel ve toplumsal bağlamında anlam kazandıklarını göstermektedir. Makineler, Deleuze'un savunduğu gibi teknik olmadan önce sosyaldir. ${ }^{49}$

Perspektif ve Öklidci geometri sayesinde elde edilen sistematik mekân duygusu Batılı kentlerin inşasında son derece işlevsel olmuştur. Batılı kent planlamasının garnizon tarzı; etrafı surlarla çevrili, Max Weber'in deyişiyle demir kafeslerle örülerek manastır görünümünde kendi içine kapanan, Michel Foucault'nun deyişiyle de panoptikon biçiminde denetime ve gözetime imkân veren yapılanması Batı dünyasının kullanılabilen, şekillendirilebilen ve dolayısıyla insan eylemi aracılığıyla hâkimiyet altına alınabilen haliyle mekân poetikası'na içkindir. Bütün dünya tamamen hareketsiz ve bütününde değişmez olarak tasarlanmıştır. Her ayrıntısına varana kadar düzenlenmiş olan, rasyonalize ve sterilize bir "ideal kent" ütopik düşüncesiyle de son derece tutarlıdır. Zaten Genesis'ten bu yana Tanrı'sıyla girdiği hesaplaşmadan kendisini bir yeryüzü cenneti yaratma görevi ve arzusuna kaptırmış olması, Hıristiyan dünyasının teolojisinin gereğiydi. "İdeal kent” bu trajedisine en uygun mekândı. Tanrı'sına rağmen bu idealini gerçekleştirmeliydi. Tanrılık iddiası bunu gerektiriyordu. Veirasse'nin yazdığı "Histoire des Sévarambes"'in 1675-1679 yılları arasında birkaç cilt halinde basılması ve Aydınlanma Çağı'nın popüler kitaplarından biri olması boşuna değildir. Nasıl ki perspektif bakış, olabildiğince güçlü ve fazlasıyla soyut düşüncelerin taleplerinin bir sonucudur ve natüralizm ile realizm kıskacında idealizme evrilmiştir,

45 Rene Descartes, Dioptrik, Meisenheim am Glan, 1954, 90 vd.'den aktaran Zeynep Sayın, “Sunuş”, Tersten Perspektif, Pavel Florenski, çev. Yeşim Tükel (İstanbul: Metis Yayınları, 2013), 11.

46 Sayın, "Sunuş", 11.

47 Sayın, Imgenin Pornografisi, 15.

48 G. Wilhelm Leibniz, New Essays on Human Understanding, trans. Peter Remnant-Jonathan Bennett (United Kingdom: Cambridge University Press, 1996), 144.

49 Gilles Deleuze, Foucault, trans. Sean Hand (Minneapolis: The University of Minnesota Press, 1988), 13. 
ideal kent tasarımı da kurgusaldır ve ütopiktir. Her ikisi de gerçekçiliği elinde tutmaya çalışan, kutsayan, tanrısal mutlaklığını ilan etmek üzere tüm gücüyle çabalayan bir düşüncenin ürünüdür.

Bütün Rönesans düşüncesini sembolik bir biçimde gösteren imge, hiç şüphe yok ki, Leonardo'nun bir dairenin ve alt köşesi bu daireyi teğet geçen bir karenin ortasında yer alan insan bedenini gösteren çalışmasıdır. Gerek mimari düzlemde gerek resimsel çizgilerde geometrik bakış açısını da içine alan bu tarz anatomik resimlerin varlığı, yani bedende varsayılan simetrik biçim, bedenleşme adına bedeni ele geçirme noktasında bir teknik sunumdur. Altın oran şeklinde mimaride de ortaya çıkan bu durum, aslında doğaya/doğala aykırı bir görme biçimi olan perspektifin uzantısı, belki de temelidir. Nitekim ilk kez Roma'da sahnelenen şehir mimarisi, ızgara planl, simetrik bir yapı arzeder. Eskiden beridir şehir ile beden bir arada zikredilirdi. Şehir planlaması beden üzerinden inşa edilir ve göbek deliği şehrin merkezi olarak belirlenirdi. 19. yüzyıla kadar mimariye yön veren, Avrupa mimari geleneğinin oluşmasında başat aktör olan Romalı mimar Vitruvius da bir binanın ölçeği ve orantısının bedenin uzuvları arasındaki ölçümden ve orandan çıkarılması gerektiğine inanıyordu. Bu insani geometrinin başka bir yansıması da kozmolojidir ki, aynı bakış açısı güneş merkezli bir şehir sisteminin inşasına sebebiyet vermişti. Kadim şehirler sonsuzluğu barındırır bir şekilde galaksi üzerinden inşa edilirken, ironik gelebilir ama Yunan ve Roma anlayışı da her ne kadar uzay üzerinden baksa da sonuçta logos merkezli olarak kozmolojiyi de oldukça hesaplı bir biçimde yeryüzüne indirmiş ve garnizon görünümünde şehirler inşa etmişlerdir. Roma döneminin Konstantinopolis'i olan bugünkü İstanbul'un perspektif bağlamında kentsel tasarımı, ilk kez Septimus Severus zamanında başlatılmış olsa da onun erken ölümü ile bıraktığı çizgiyi tekrar ele alma ve tamamlama işi imparator Konstantin'e kalmıştır. Bugün divan yolu olarak anılan kentin ana aksı hüviyetindeki mese yolu, tam da bu perspektif anlayışının mekânsal uzanımı için tipik bir örnektir. Bulvar anlayışıyla kenti doğrudan ikiye bölmesinin yanında her tepe için birer form (meydan) oluşturması, mekânı ele geçirme ve mekîn olanları da her an gözetleme imkânını vermiştir. Formların ortasına, o formu yaptıran imparator anısına tanrısal bir heykelin konulması, kalabalığın her an gözetlenmesi ve ele geçirilmesi açısından oldukça tehditkâr bir anlam içerir.

Kente kimliğini veren en bariz düşünce düzen'dir. Her şeyde her yerde görülen, görülmesi istenen logos, alfabeyi sesli harflerle ve dili gramerle, sonra düşünceyi mantıkla, anlatıyı dramla düzene sokarken, görüntüyü de perspektifle düzene sokmuştur. Kente dair her şey hesaba katılmıştır. Şehirlerle ilgili seçimler, yollar ve düzenlemeler simetri ve açılılk prensibinin göstergesidir. Kaotik hiçbir şey yoktur. Modernliğin tahammül edemediği müphemliğe kurduğu kentte de yer verilmemiştir. Caddeleri geniş ve öylesine düzdür ki adeta cetvelle çizilmiş gibidir. Böylesi kentlerde meydan esastır. Kentlerde ihdas edilen meydan mefhumu, kentlerin garnizon tarzı inşasında hiyerarşiye dayalı toplumsal ve sınıfsal ayrımları kaçınılmaz kılan, aynı zamanda 
kenti ve halkını savunma ve korunma mekanizmasıyla içe kapatan bir yapılanma tarzıdır. Haddizatında kentlerin garnizon tarzında inşa edilmesi, Roma askeri kamplarından mülhemdir. Hâlbuki "İslam șehirlerinin bir meydanı, halkın günlük faaliyetlerini sürdürdüğü bir agorası yoktur. Burada merkezi oluşturan mekânsal unsur, hayatın da merkezi unsurunu teşkil eden dindir. Din o kadar hayatın merkezinde ve kendisindedir ki, dini-dünyevi ayrımına pek fırsat kalmaz. Öte yandan camiyle birlikte inşa edilen medresenin dişında, halkın eğitimi için (ders-i âm) camiye düzenli dersler konulurken, mahkemelerin de yine buralarda bulunması önemlidir. Cami, neredeyse bütün sosyal ve kültürel hayatı cem eden mekândır." ${ }^{50}$ Şehir her zaman için bütünlüğün bir imajı olmuştur; onun biçimi insanın kendisini âlemle bütünleştirme tarzını gösterir. Ana eksenler boyunca yayılan kare şeklinde bir kent yerleşik hayatın ve düşüncenin, aynı zamanda evrenin statik bir imajının ifadesi olurken, daire şeklinde tasarlanmış bir şehir dinamik bir âlem anlayışının tezahürü olarak değerlendirilmektedir.

\section{Kent Mekânında Seküler Dinin İnşası}

Mekânın haritalar sayesinde bütünselleştirici bir bakış açısı ile parsellenmesi, toplumsal hayata, kamusal alan ve özel alan şeklinde ayrıştırarak müdahaleyi de açık hale getirmiştir. Kamusal alanın Kant sonrasında rasyonellikle karakterize edilmesi, “insanın iç dünyasına ait” bir inancın karşılığı olarak kullanılmaya başlanan religionın kamusal alandan çekilmesinde etkili olmuştur. John Locke gibi önemli kamu figürlerinin, Tanrı'yla ilgili inanışları özel bir alanda izole etme çabası dinin belli mekânlara hapsedilmesine yol açmıştır. Başka bir deyişle din, kentin toplumsal hayatına dışlama siyaseti üzerinden dâhil olur. Zira kentin ve kentsel toplumsal yaşamın sınırını çizen, dolayısıyla bunların kurulmasını mümkün kılan şey, dışlama siyasetidir. Asıl dışarıda tutulanlar modern kentin kimliğini yaratır. Benzersiz, saf kimliğini oluşturmak için bu "dışarıya" ihtiyacı vardır. Din, kamusal yaşamın dışına terk edilirken, tersinden kamusal mekânın sınırını da belirlemiş olur. Kent mekânının merkez-çevre şeklinde parçalanması, “yaşam, özgürlük, sağlık, varlık, toprak, para gibi dış dünyaya ait” şeylerin seküler alanlar olarak kamunun çıkarları için müdahale edilebilir olarak algılanmasına, religionın ise "iç dünyaya ait, sekülerden ayrı ve siyasi otoriteden korunmuş alanı" oluşturmasına karar verilmiştir. Sosyoloji'nin kurucularından Emile Durkheim'ın din ve toplum görüşü de birbirinden bağımsız, dışlayıcı ve bölünmüş kavramsal kategorilerden oluşur. Durkheim'a göre, bilinen bütün basit ya da karmaşık dinî inançlar tek bir temel özelliğe sahiptir. "Bunlar insanların üzerine düşündükleri her şeyin (gerçek ya da ideal) iki sınıfa ya da karşıt gruba ayrıldı̆̆ını varsayar. Bu sınıflar genellikle bizim profane (dindişı) ve sacred (kutsal) diye iyi bir çeviriyle karşıladığımız iki terimle ifade edilir (profane, sacred). Dünyanın bu şekilde biri kutsal diğeri dindışı olan her şeyi kapsayan iki alana bölünmesi dinî düşüncenin

50 Celaleddin Çelik, “İslam Şehri’nden Şehir İslamı'na: Tarihsel Tecrübeden Sosyolojik Pratiğe Şehrin Medeniyet Kodları”, Milel ve Nihal 9/3 (Aralık 2012), 147. 
alametifarikasıdır." ${ }^{51}$ Mucize kelimesini içeren ifadenin aynı zamanda lanet anlamını da içermesi, dikotomik anlayışın tek bir kelimede bile kendini açık etmesi açısından dikkate şayandır.

Bilindiği gibi Din Sosyolojisi de bilimsel bir disiplin olarak konu, yöntem ve yaklaşımları çerçevesinde toplumsal alanı sosyolojik açıdan analiz ederken, "kutsal olan ve olmayan" ayrımından hareket etmektedir. Dolayısıyla bu hareket tarzı Batı düşüncesinin Platon'dan başlayarak devam edegelen karşıt değerler üzerine kurulu metafizik karakteriyle tutarlılı arz etmektedir. Ayrıca burada dikkat edilmesi gereken nokta, bilimsel bir disiplin olarak bilinen Din Sosyolojisi'nin Hiristiyan teolojisi üzerine temellenmiş olmasıdır. Aziz Augustine 5. yüzyılda yazdığı Tanrının Şehri (De Civitate Dei Contra Paganos) isimli eserinde "İnsanın Șehri ve Tanrının Şehri olmak üzere birbiriyle çatışan iki farklı dünyadan bahsetmektedir. Aziz Augustine'in ifadesiyle İnsanın Şehri paganların yaşadıkları, geçici, fani, temel karakteristiği günah olan bir dünya olup maneviyatın timsali olan Tanrının Şehriyle zıtlık arz etmektedir." ${ }^{\prime 2}$ Eserinde seküler kelimesinin de kökeni olan saeculum sözcüğünü hem zaman hem de uzamsal bir kavram olarak kullanmaktadır. Buna göre hoc saeculum yani bu âlem, "Tanrının Şehrini temsil eden Hıristiyanlık dışında kalan profan dünyaya işaret etmektedir." ${ }^{53}$ Dolayısıyla kutsal ve profan ayrımını, "İsa'nın tanrısal ve insanî yönü" ${ }^{54}$ ve yine "yeryüzü krallığı ve gökyüzü krallığı" ya da "iki kılıç teorisi” biçimindeki H1ristiyan teolojisinin tezahürü olarak düşünmek mümkün görünmektedir. "Din ile iktidarı ayırmak, Reform-sonrası özgül tarihsel sürecin ürünü olan modern Batılı bir normdur." ${ }^{25}$ Seküler-dinî ikiliği modern devletlerin oluşumunda rol oynayan yeni bir anlayıs getirir. Öyle ki Fitzgerald'a göre, modern devlet kavramının oluşumu, modern, özelleştirilmiş din kavramının anlaşılmasında temel öneme sahiptir. ${ }^{56}$ Dünyanın bu anlamda ikiye bölünmesi bu devletlerin bireyci antropolojisiyle uyumludur.

Böylesine bir kent planlamasında bütün dünya artık, perspektif marifetiyle icat edilen önce camera obscura, sonra stereoskop gibi cihazların, son olarak da panoptiktarzı kapanım üzerine kurulu bir sistemin devreye sokulmasıyla tiyatro gibi sunulduğu bir sahne halini almaktadır. İngiliz Rönesans edebiyatı, perspektifin sağladığı bu yeni mekân duygusunun edebi gösterim tarzları üzerindeki büyük etkisine tanıklık etmektedir. Shakespeare'in ya da John Donne ya da Andrew Marwell gibi şairlerin dili bu tür imgelerle doludur. Oysaki "Yanılsama ve aldatmaca üzerine kurulu Antik Yunan tiyatrosundan soluklanan ve izleyiciyi tıpkı Platon cehennemindeki mahkûmlar gibi

51 Emile Durkheim, The Elementary of the Religious Life, trans. Joseph Ward Swain (New York: The Macmillan Company, 1915), 37.

52 Ekber Şah Ahmedi, “Sekülerleşme: Soykütüksel Bir İnceleme”, AKID 1/1 (2018), 60.

53 Ahmedi, "Sekülerleşme: Soykütüksel Bir İnceleme", 61.

54 Rudolf Otto, Kutsal'a Dair: Kutsal Tasarısındaki Sezgisel Faktör ve Rasyonele Olan İlişkisi Üzerine Bir Araştırma, çev. Sevil Ghaffari (istanbul: Altıkırkbeş Yayınları, 2014), 92.

55 Talal Asad, Dinin Soykütükleri, Hiristiyanlikta ve İslam'da İktidarın Nedenleri ve Disiplin, çev. Ayet Aram Tekin (Istanbul: Metis Yayınları, 2015), 43.

56 Timothy Fitzgerald, Discourse on Civility and Barbarity, A Critical History of Religion and Related Categories (New York: Oxford University Press, 2007), 268. 
sıralara zincirleyen, onu tek bir gözü varmış ve o da hareketsizmiş gibi davranmaya zorlayan bir tavırdır bu." ${ }^{57}$ Hâlbuki Osmanlı'da bugün onlara gösteri sanatı denen çeşitli sanatsal mekânlar -Karagöz'ün hayal perdesi, şenliklerin düzeni vb.- gösteri sanatının mekânıyla birlikte değișen farklı yorumlara imkân tanımaktaydı. "Kullanılan malzemeyle beraber değişen biçim, sürekli farklılaşan, her an yeni baştan var olan bir uzay anlayışının göstergesidir. Mekânın, içinde yer aldığı malzemeye -maddeye- göre eylemesinin nedeni, Müslüman mekân anlayışının, Rönesans sonrası Avrupa'nın mekân anlayışından oldukça farklı olmasından kaynaklanmaktadır. Çünkü mekân, aynı zamanda bir madde ve bir kuvvedir." ${ }^{58}$ Mekân kendi içsel dokunusuvla kendini dönüstürmeve kadirdir. "Mekân ne tek biçimli ve vapılanmamıs bir mekândır ne de basit bir kategoridir. Aksine özgül, zaman içinde düzenlenmis bir gerçekliktir ve bu gerceklik her yerde farklılıklar gösterir, dahası içsel bir düzene ve içsel bir yapıya sahiptir." 59 "Mekân her zaman her yerde istediği türden değişim gösterebilir. Resim yüzeyinde arka planının doldurulmaması, mekânı başkalaşımlara açık tutmak içindir. Dolayısıyla içinde yer aldığı mekâna göre biçim değiştiren bir mekân anlayışı, farklı temsil biçimlerinde mekânla birlikte değişen farklılıklara ihtiyaç duyacaktır." ${ }^{60}$ Mekânın koordinatlarını alarak onun kendine dönüşmek, İbn Arabi terminolojisiyle söyleyecek olursak, yer aldığı mekâna öykünmektir. ${ }^{61}$ Tam bu noktada hümanist perspektiften mülhem, açıklı, rasyonellik, düzenleme ve nesnellik ilkeleriyle örülü Batılı mekân poetikasının Aristo'dan miras kalan dramaturjiyle olan benzerliğine de dikkat çekmek yerinde olur. Kökenini Poetika'dan alan herhangi bir edebi anlatının belli bir mekân ve belli bir zaman ile kayıt altına alındığı dram birliğinin tersine; "Doğu" hikâyelerinde tıpkı resimde perspektifin inkârı gibi zaman ve mekân kaydından azade oluş, aynı estetik prensiplerin farklı tezahürleri olarak değerlendirmeye imkân tanımaktadır. "Doğu" hikâyelerini oluşturan, farklılık arz eden olay örgüsünde, farklı zaman ve mekânlara geçilebilmektedir. "Perspektifin inkârıyla mekân ve buna bağlı olarak zaman ortadan kalktığı için böyle bir sahnede her şey olasılık dâhilindedir." ${ }^{62}$ Burada tek bir doğru bakış açısı olduğu iddiasındaki perspektiften mülhem modernliğin aksine, farklılığa alan açan, müphemliğe imkân veren, dikte etmeden, sınırlandırmadan, başka türlü nasıl anlatılabilirin arzusunda olan bir dünya görüşü söz konusudur. Sözlü ve yazılı kültürüne sirayet etmiş olan bu çok katmanlı ve çok anlamlı anlatı tarzı görsel kültürü için de geçerlidir. Nitekim minyatürlerde tekli değil, çoklu bir bakış açısı, çoklu perspektif söz konusudur. Ayrıştırıcı kimlik politikalarıyla baş etmek durumunda kalan günümüz dünyasının ihtiyacı, bu çoklu perspektif geleneği olsa gerektir.

\footnotetext{
57 Sayın, "Sunuş", 10.

58 Sayın, "Sunuş", 28.

59 Florenski, Tersten Perspektif, 52.

60 Sayın, Imgenin Pornografisi, 65.

61 İbn-i Arabi, Fususu'l Hikem Tercüme ve Șerhi, çev. M Tarhanlı-S. Eraydın (İstanbul: Marmara Üniversitesi İlahiyat Fakültesi Vakfi Yayınları, 1989-1992), 97-99'dan aktaran Sayın, “Sunuş”, 29.

62 Beşir Ayvazoğlu, Aşk Estetiği, İslam Sanatlarının Estetiği Üzerine Bir Deneme (İstanbul: Kapı Yayınları, 2016), 163.
} 
Herman Melville, modernleşme öncesi Konstantinopolis'te bulunduğu sırada günlüğüne "Sokakların hiçbir planı yok. Tam bir labirent. Dar, kapalı. Ah bir üzerine yükselebilsem... Ama nerede?.. Sokakların adı yok... Numara yok... Hiçbir şey yok" diye not düşmüştü. Melville'yi şaşırtan şey, şehrin bir resim olarak görülmesini sağlayan, panoramik bakış açısına imkân vermemesiydi. Şehir, herhangi bir plandan yoksun görünüyordu. Avrupalılar, gözlemci ile gözlemlenen nesne arasına konan mesafe sayesinde, "şeylerin kendilerinin" dışında duran bir şeyler olmasını bekliyorlardı. Oysa Ortadoğu şehrinde hiçbir şey dışarıda durmuyor, kendini yabancılara, gözlemci özneye temaşa nesnesi olarak sunmuyordu. Sokakların adı yoktu, yollarda işaret yoktu, belirgin façade'ların bulunduğu açık alanlar yoktu, harita yoktu. Şehir kendini, bir şeyin temsili olarak sunmayı reddediyordu, çünkü zaten bu niyetle kurulmuş değildi. Başka bir deyişle, ayrı bir planın ya da anlamın var olduğu efektini yaratacak şekilde düzenlenmemişti. Örneğin bir Kuzey Afrika evinin düzenlenişi, şeyler ile bir örüntü veya bir plan arasındaki ilişkiyle ilgilenmez. Bu tür evlerin düzeni, dünyaya kendisinin nesnesi gibi yaklaşan yalıtılmış bir özne üzerine kurulu bir düzen değildir. Bu birey-öznenin dünya ile bu dünyanın planı ya da temsili arasındaki ilişkiyi sabitleştirmesi meselesi olarak anlam, onu ilgilendirmez; ne de bu temsilin kesinliği olarak hakikat. Batılı bakış açısına göre ise, her şey, izleyen bir öznenin gözleri için, bir göstergeler sistemi gibi düzenlenmiştir. Her şey sanki bir şeyin modeli ya da resmiymiş gibi tasarlanmış bir şekilde insanın önünde belirmektedir. Her şey bir gösterilenin bir göstereni olduğunu ilan etmektedir. Mesele kendini dünyadan ayırmak ve onu bir panorama olarak kurmaktır.

\section{Sonuç}

Formlar, "orada öylece duran" dış gerçeklik hakkında, "kim olsa aynı şeyi” görüp düşüneceği bir "nesnel doğruluk” düşüncesiyle karakterizedir. Dış dünyanın gerçekliğini temsil etme iddiasındaki bu formlar, aslında verili bir gerçekliğin simülakrını üretmektedir. Buna rağmen temsili mümkün kılan ise, insanın dünyada olduğundan, dünyanın insana sunulduğundan şüphe duyulmamasıdır. Görüntüye duyulan güven, her öznenin aynı bakış açısıyla sahip olabileceği nesnel görüşü koyutlar. Perspektifin icadıyla görü ve bilginin eşitlenmesi, "dünyanın büyüden arındırılması" sürecine ilk atılımdır. Nesneler dünyasını onlara form vererek geometrik bir düzen içine yerleştiren, dolayısıyla da anlam bahşeden bir görme rejimi olarak perspektif, dünyayı belli bir tarzda düzenleme arzusunun dışavurumudur. Keza aynı ölçüde hem dış dünyanın sabitlenmesi ve sistematikleştirilmesi hem de karşıdan bakılabilir ve denetlenebilir bir mekâna dönüşmesi sağlanmış olmaktadır. Haritalar sayesinde elde edilen bütünselleştirici bakış açısı, statik mekân poetikasına içkindir. Mekânın hareketsiz ve değişmeyen bir olgu olarak tasavvur edilmesi, mekân üzerinde düzenlemeyi ve müdahaleyi mümkün kılar. İnsanbiçimci ve hümanist her müdahale esasında seküler bir pratiktir. Mekâna seküler bakış, mekânın seküler ve dinî şeklinde parsellenmesine yol açmıştır. Toplumsal hayatı kamusal ve özel olmak üzere ikiye ayırmak, kamusal mekânı rasyonel ve nesnel olanla, özel alanı ise irrasyonel ve sübjektif olanla 
karakterize etmek, mekâna seküler bakıştır. Dinin de insanın iç dünyasına hitap eden özel alanla ve belli ibadethane mekânlarıyla sınırlandırılması, irrasyonel olarak nitelendirilmesi, rasyonel seküler alan karşısında değillenmesi, ötelenmesi için elzemdir. Bu yüzden olsa gerek, dinin kamusal mekânda görünürlüğünün artması, seküler alanın işgale uğraması olarak algılanmaktadır. O yüzdendir ki, dinin belli bir mekâna hapsedilmesi, dinin kontrolü için vazgeçilmezdir.

Peki, “Şimdi ne olacak?”. Bu soru aynı zamanda bütün tuhaflığı ve gizemi ile her şeyi gören gözü simgeleyen Alberti'nin ambleminin altında bir motto olarak yazılıdır: "Quid tum?". Görü ile bilgiyi eşitleyen Batı düşüncesine en iyi cevabı modern toplumu panoptik toplum olarak nitelendiren Foucault veriyor: "Görünürlük tuzaktır."

Etik Beyan / Ethical Statement

Yazar / Author
Bu çalışmanın hazırlanma sürecinde bilimsel ve etik ilkelere uyulduğu ve yararlanılan tüm çalışmaların kaynakçada belirtildiği beyan olunur / It is declared that scientific and ethical principles have been followed while carrying out and writing this study and that all the sources used have been properly cited. İrfan Kaya

\section{Kaynakça}

Ahmedi, Ekber Şah. “Sekülerleşme: Soykütüksel Bir İnceleme”. AKiD 1/1 (2018), 57-70.

Asad, Talal. Dinin Soykütükleri, Hiristiyanlıkta ve İslam'da İktidarın Nedenleri ve Disiplin. çev. Ayet Aram Tekin. İstanbul: Metis Yayınları, 2015.

Ayvazoğlu, Beşir. Aşk Estetiği, İslam Sanatlarının Estetiği Üzerine Bir Deneme. İstanbul: Kapı Yayınları, 2016.

Baxandall, Michael. 15. Yüzylda Sanat ve Deneyim. Stilin Toplumsal Tarihine Giriş. çev. Zeynep Rona. İstanbul: İletişim Yayınları, 2015.

Bazin, Andre. Çağdaş Sinemanin Sorunları. çev. Nijat Özön. Ankara: Bilgi Yayınevi, 1966.

Belting, Hans. Floransa ve Bağdat, Doğu'da ve Batı'da Bakışın Tarihi. çev. Zehra Aksu Yılmazer. İstanbul: Küy Yayınları, 2017.

Berger, Peter.-Luckmann, Thomas. Gerçekliğin Sosyal İnşası, Bir Bilgi Sosyolojisi İncelemesi. çev. Vefa Saygın Öğ̈̈tle. Ankara: Atıf Yayınları, 2018.

Cassirer, Ernst. The Philosophy of Symbolic Forms Volume I: Language. trans. Ralph Manheim. New Haven - London: Yale University Press, 1980.

Çelik, Celaleddin. “İslam Şehri'nden Şehir İslamı'na: Tarihsel Tecrübeden Sosyolojik Pratiğe Şehrin Medeniyet Kodları". Milel ve Nihal 9/3 (Aralık 2012), 137-156.

Deleuze, Gilles. Foucault. trans. Sean Hand. Minneapolis: The University of Minnesota Press, 1988.

Durkheim, Emile. The Elementary of the Religious Life. trans. Joseph Ward Swain. New York: The Macmillan Company, 1915.

Fanon, Frantz. Siyah Deri Beyaz Maskeler. çev. Cahit Koytak. İstanbul: Encore Yayınları, 2016.

Fitzgerald, Timothy. Discourse on Civility and Barbarity, A Critical History of Religion and Related Categories. New York: Oxford University Press, 2007. 
Florenski, Pavel. Tersten Perspektif. çev. Yeşim Tükel. İstanbul: Metis Yayınları, 2013.

Goodman, Nelson. Ways of Worldmaking. Indiana: Hackett Publishing, 1978.

Harvey, David. Postmodernliğin Durumu, Kültürel Değişimin Kökenleri. çev. Sungur Savran. İstanbul: Metis Yayınları, 2014.

Heidegger, Martin. Nietzsche’nin Tanrı Öldü Sözü ve Dünya Resimleri Çağı. çev. Levent Özşar. Bursa: Asa Yayınları, 2001.

Holly, Michael Ann. Panofsky ve Sanat Tarihinin Kökleri. çev. Orhan Düz. İstanbul: Dedalus Yayınlar1, 2016.

Jay, Martin. “Scopic Regimes of Modernity”. ed. Hal Foster. Vision an Visuality. 3-28. Seattle: Bay Press, 1988.

Jay, Martin. Downcast Eyes: The Denigration of Vision in Twentieth-Century French Thought. Berkeley and Los Angeles: University of California Press, 1993.

Karatani, Kojin. Metafor Olarak Mimari. çev. Barış Yıldırım. İstanbul: Metis Yayınları, 2017.

Karatani, Kojin. Derinliğin Keşfi. çev. Devrim Çetin Güven-İnan Öner. İstanbul: Metis Yayınları, 2011.

Kaya, İrfan. "Sosyolojik Düşüncede Avrupa-merkezcilik, Ötekileştirme ve Oryantalist Söylem Üzerine Post-kolonyal Bir Okuma ve Eleștirisi”. Cumhuriyet İlahiyat Dergisi 21/3 (Aralık 2017), 1973-2008.

Lacan, Jacques. Psikanalizin Dört Temel Kavramı. çev. Nilüfer Erdem. İstanbul: Metis Yayınları, 2019.

Leibniz, G. Wilhelm. New Essays on Human Understanding. trans. Peter Remnant-Jonathan Bennett. United Kingdom: Cambridge University Press, 1996.

Otto, Rudolf. Kutsal'a Dair: Kutsal Tasarısındaki Sezgisel Faktör ve Rasyonele Olan İlişkisi Üzerine Bir Araştırma. çev. Sevil Ghaffari. İstanbul: Altıkırkbeş Yayınları, 2014.

Panofsky, Erwin. Gotik Mimarlk ve Skolastik Felsefe, Ortaçağda Sanat, Felsefe ve Din Arasındaki Benzerliklerin İncelenmesi. çev. Engin Akyürek. İstanbul: Kabalcı Yayınları, 2014.

Panofsky, Erwin. Perspektif. Simgesel Bir Biçim. çev. Yeşim Tükel. İstanbul: Metis Yayınları, 2013. Sayın, Zeynep. İmgenin Pornografisi. İstanbul: Metis Yayınları, 2013.

Sayın, Zeynep. “Sunuş”. Tersten Perspektif. Pavel Florenski. çev. Yeşim Tükel. 7-36. İstanbul: Metis Yayınları, 2013.

Sennett, Richard. Beden ve Taş, Batı Uygarlı̆ında Beden ve Şehir. çev. Tuncay Birkan. İstanbul: Metis Yayınları, 2014.

Simmel, Georg. Modern Kültürde Çatışma. çev. Tanıl Bora vd. İstanbul: İletişim Yayınları, 2017. Wittgenstein, Ludwig. Tractatus-Logico Philosophicus. çev. Oruç Aruoba. İstanbul: Metis Yayınları, 2013. 